Contato 45083-900 - Vitória da Conquista - BA galvaocarvalho@uol.com.br

\section{O SUBSTANTIVISMO POLANYIANO E OS NOVOS MODELOS DO MERCADO NA MESOPOTÂMIA}

\author{
Alexandre G. Carvalho*
}

Universidade Estadual do Sudoeste da Bahia Vitória da Conquista - Bahia - Brasil

\title{
Resumo
}

A reflexão sobre o mercado é um tema caro ao substantivismo polanyiano. Em seu modelo da economia antiga, Karl Polanyi defendeu a preponderância da reciprocidade e redistribuição em detrimento do mercado autorregulável no mundo antigo. Os assiriólogos, sejam os defensores fervorosos do modelo polanyiano, como Johannes Renger, ou os críticos ferozes a tal modelo, como Morris Silver, têm debatido o papel do mercado no antigo Oriente Próximo em meio a outras interpretações que procuram reinterpretar as mais diversas fontes textuais e arqueológicas da sociedade mesopotâmia em diversos períodos, como, por exemplo, o trabalho de Mario Liverani. Ao analisar os argumentos desses autores paradigmáticos, pretende-se, neste artigo, por meio da apresentação e repercussão do modelo polanyiano, apresentar um amplo painel crítico do debate sobre a economia e a sociedade na Mesopotâmia.

\section{Palavras-chave}

Karl Polanyi - economia antiga - Mesopotâmia - mercado.

* Doutor em História Social pela Universidade Federal Fluminense. Professor titular do Departamento de História da Universidade Estadual do Sudoeste da Bahia (Uesb). 

45083-900 - Vitória da Conquista - BA galvaocarvalho@uol.com.br

\section{THE POLANYIAN}

SUBSTANTIVISM AND

THE NEW MODELS

OF THE MARKET IN

MESOPOTAMIA

\section{Alexandre G. Carvalho}

Universidade Estadual do Sudoeste da Bahia

Vitória da Conquista - Bahia - Brazil

\begin{abstract}
The reflection on the market is a fundamental topic of substantivism. In his model of the ancient economy, Karl Polanyi defended the preponderance of reciprocity and redistribution at the expense of self-regulating market in the ancient world. Assyriologists, be they fervent defenders of the Polanyian model, as Johannes Renger, or fierce critics of such model, as Morris Silver, have discussed the role of the market in the ancient near East along with other interpretations that seek to reassess the several archaeological and textual sources of the Mesopotamian society in various periods as in the work of Mario Liverani. By analyzing the arguments of these paradigmatic authors in this paper, I intend to propose an ample critical view of the discussion on the economy and society in Mesopotamia.
\end{abstract}

\title{
Keywords
}

Karl Polanyi - ancient economy - Mesopotamia - market. 
O papel do mercado no seio do centenário debate da economia antiga ainda continua sendo motivo de contendas e reflexões. Abordá-lo em meio ao debate da economia mesopotâmia mostra-se relevante em vista de um emaranhado de opiniões de historiadores, antropólogos e sociólogos com paradigmas e modelos de suas áreas de conhecimento de orientações diversas que compõem um quadro multifacetado, mas ainda instigante por suas relações com a realidade em que vivemos. Ao explorar os argumentos do substantivismo e suas consequências em relação à economia mesopotâmia, explicitando as posições favoráveis e contrárias, sem adentrar em novidades recentes das pesquisas empíricas sobre o tema, pois isso demandaria um exame direto da documentação cuneiforme, procuraremos apresentar um panorama da questão, a fim de esclarecer como o tema tornou-se um objeto de pesquisa histórica e como se formularam algumas posições referenciais do debate.

\section{O mercado no seio do substantivismo polanyiano}

No livro A grande transformação, publicado em 1944, gestado entre $1941 \mathrm{e}$ 1943 nos Estados Unidos a partir das notas de cursos noturnos ministrados sobre história econômica e relações internacionais nas pequenas cidades de Kent e Sussex na Inglaterra, Karl Polanyi afirmou que a sociedade do século XIX foi econômica em um sentido diferente e distinto das anteriores, pois foi baseada no lucro. Esta sociedade adquiriu sua maturidade na Inglaterra, na esteira da Revolução Industrial, durante a primeira metade do século XIX e, cinquenta anos depois, alcançou a América do Norte. ${ }^{1}$

A característica fundamental desta revolução foi o estabelecimento da economia de mercado, cuja natureza só pode ser totalmente apreendida a partir do impacto das máquinas conjugadas com os estabelecimentos fabris em uma sociedade comercial. Tal transformação implicou uma mudança na motivação da ação das pessoas: o lucro suplantou a motivação pela subsistência. As transações assumiram um caráter monetário que exigiu a introdução de um meio de intercâmbio em cada articulação da vida industrial. Todas as rendas passaram a derivar das vendas de alguma coisa.

O sistema de mercado designa um padrão institucional, o do mercado, que funciona sem qualquer interferência externa. Os preços, resultantes das transações, em vez de as precederem, têm a liberdade de se autorregularem,

\footnotetext{
${ }^{1}$ POLANYI, Karl. A grande transformação: as origens da nossa época. Tradução de Fanny Wrobel. $8^{\mathrm{a}}$ edição. Rio de Janeiro: Campus, 2000, p. 47.
} 
não sendo mais sociais, culturais ou políticos, mas, sim, econômicos. Este sistema, capaz de organizar a totalidade da vida econômica sem qualquer ajuda, é chamado de autorregulável. Daí a perspectiva de que a sociedade liberal não apenas englobe uma economia de mercado, mas que ela seja uma sociedade de mercado, em que a sociedade se acha imersa (embedded) na economia de mercado e não o inverso.

Polanyi não nega a existência de mercados antes da sociedade do século XIX. Contudo, tais mercados tinham um papel apenas incidental na vida econômica. Portanto, tais economias não eram controladas pelo mercado. Somente a partir do século XVI, os mercados passaram a ser mais numerosos e importantes, mas ainda não controlavam a sociedade, pois não eram autônomos, mas, sim, acessórios de uma estrutura institucional controlada e regulada pela autoridade social.

Para Polanyi, a Revolução Industrial é indissociável de uma transformação institucional importante que visa o estabelecimento de uma rede de mercados aptos a determinar a estrutura da sociedade. Ele demonstra que a economia de mercado que se propaga plenamente no século XIX não pode ser entendida sem uma série de ações políticas que contribuem largamente para instituir os comportamentos individuais típicos dessa economia. Assim, ao mostrar a importância da política na história econômica, Polanyi questiona as políticas neoliberais que procuram atribuir um caráter "espontâneo" aos mecanismos do mercado. O surgimento da sociedade liberal não é o resultado de uma evolução espontânea e natural, mas de uma forma de decisão política e ideológica. Mais especificamente, o mercado moderno e o Estado moderno aparecem conjuntamente, e o primeiro como um subproduto do segundo. Polanyi argumenta que as sociedades tradicionais e os grandes impérios arcaicos têm resistido a tudo o que vai em direção a uma autonomização do econômico e do mercado e como, simetricamente, a emergência do mercado autorregulável no Ocidente moderno não é fruto espontâneo de uma evolução natural, mas o resultado de uma ficção ideológica e de um projeto de Estado. ${ }^{2}$

A abordagem polanyiana sobre o mercado faz parte de um paradigma institucionalista em economia que dá às "instituições" um significado especial. Segundo Maucourant, a instituição é que dá estabilidade aos comportamentos individuais, condição da vida social. É, portanto, um arranjo particular das partes em relação a toda a sociedade e se refere a fatores

2 MAUCOURANT, Jérôme. Avez vous lu Polanyi? Paris: Flamarion, 2011, p. 20-22. 
psicológicos, sociais e econômicos. Para Maucourant, a instituição assim entendida está muito próxima do conceito de "fato social total", desenvolvida por Mauss. Nas instituições, é possível entender as modalidades do processo de reprodução social. Nessa perspectiva, a concepção polanyiana objetiva compreender como se institucionalizam os processos de mercado, posto que o mercado, como princípio organizador da economia, não cria as condições de regulação e não tende ao equilíbrio, pois não produz espontaneamente as instituições que são a condição sine qua non de funcionamento dos mercados concretos. Daí a necessidade de explicar a construção social dos mercados e sua inclusão nas relações de poder. ${ }^{3}$

As atividades sociais e as instituições são econômicas quando fazem parte das atividades econômicas. Os elementos econômicos podem agrupar-se como ecológicos, tecnológicos ou sociais segundo pertençam ao entorno natural, ao equipamento mecânico ou à sociedade humana. Porém, sem as motivações sociais que determinam as motivações dos indivíduos, não haveria nada que sustentasse a interdependência dos movimentos e sua recorrência, necessários para a unidade e para a estabilidade da atividade econômica. Para adquirir a coerência de uma economia real, o processo de interação deve ser institucionalizado. É a combinação de elementos humanos e naturais, a interdependência da tecnologia e as instituições, assim como sua independência relativa, que são compreendidas pela atividade econômica institucionalizada. Portanto, a economia humana encontra-se integrada e submergida em instituições econômicas e não econômicas. Com efeito, a religião ou o governo podem ser tão importantes quanto as instituições monetárias para a estrutura econômica. O estudo do lugar cambiante que ocupa a economia na sociedade é a análise de como está institucionalizada a atividade econômica em diferentes épocas e lugares e deve começar pela forma como a economia adquire unidade e estabilidade, isto é, pela interdependência e a regularidade de suas partes. Tal unidade é resultado de formas de integração, que se manifestam em diferentes níveis e em distintos setores, impossibilitando-nos de selecionar uma delas como dominante para classificar os diferentes tipos de economias. Contudo, tais formas de integração constituem um instrumento para descrever a atividade econômica em

\footnotetext{
3 Esta perspectiva institucionalista é amadurecida no livro Trade and market, coletânea escrita em 1957, fruto do trabalho em um programa de pesquisa interdisciplinar, na Universidade de Columbia, da qual Polanyi foi professor visitante.
} 
termos comparativamente simples, permitindo-nos ordenar as infindáveis variações dessas formas. ${ }^{4}$

As principais formas de integração são a reciprocidade, a redistribuição e o intercâmbio, segundo a observação empírica. Além dessas três formas de integração, Polanyi também analisou a household (oikos) ${ }^{5}$ no livro A grande transformação, porém a excluiu de Trade and market, pois a household abrangia um grupo menor, caracterizado pela ausência das relações intergrupais. Polanyi ampliou esses conceitos para além das formações primitivas.

A reciprocidade supõe movimentos entre pontos correlativos de agrupações simétricas; a redistribuição consiste em movimentos de apropriação em direção a um centro primeiro e, posteriormente, desse centro para fora outra vez. Por intercâmbio, entendemos movimentos recíprocos como os que realizam os "sujeitos" em um sistema de mercado. Polanyi ressalta que os meros agregados das condutas individuais não bastam para produzir as estruturas. A conduta de reciprocidade entre os indivíduos só integra a economia se já existirem estruturas organizadas simetricamente, como os sistemas simétricos de grupos unidos pelo parentesco. Do mesmo modo, a redistribuição pressupõe um centro para onde se dirigem os recursos da comunidade. Finalmente, os atos de troca no plano individual só produzem preços se estiverem enquadrados em um sistema de mercados criadores de preços, uma estrutura que não sugere, de forma alguma, atos de troca efetuados ao acaso. ${ }^{6}$ Polanyi tratou as ações de comportamento de acordo com os princípios de reciprocidade e redistribuição e reconheceu que essas formas de comportamento estavam ligadas à existência de estruturas sociais determinadas - um exemplo característico de explicação funcional. Segundo Mihály Sárkány,7 o conceito de economia como um processo institucionalizado está ligado às tendências da escola institucionalista americana e abordagens da escola histórica de teoria econômica. Seus paralelos também podem ser achados na análise institucional da antropologia social britânica, na qual o aspecto de integração social teve um papel central.

\footnotetext{
${ }^{4}$ POLANYI, Karl; ARENSBERG, Conrad; PEARSON, Harry. Comercio y mercado en los imperios antiguos. Tradução de Alberto Nicolás. Barcelona: Labor Universitaria, 1976, p. 294-296.

5 O termo refere-se à unidade doméstica, isto é, produção para uso próprio. O princípio é o de produzir e armazenar para a satisfação das necessidades dos membros do grupo.

6 POLANYI, Karl; ARENSBERG, Conrad; PEARSON, Harry. Comercio y mercado en los imperios antiguos. Op. cit., p. 296-297.

7 SẤRKANY, Mihály. Karl Polanyi's contribution to economic anthropology. In: LEVITT-POLANYI, Kari. The life and work of Karl Polanyi. Montreal: Black Rose Books, 1990, p. 184-186.
} 
O mercado, do ponto de vista da economia formal, é o lugar onde se efetua a troca, pois estes dois elementos são inseparáveis. A vida econômica se reduz a atos de troca realizados por meio do regateio no mercado. Assim, a troca é $a$ relação econômica e o mercado é $a$ instituição econômica. A definição do mercado deriva logicamente dessas premissas. Na realidade, contudo, mercado e troca têm características empíricas independentes. A troca é, em essência, um movimento mútuo de apropriação de produtos entre sujeitos, sujeita a equivalências fixas ou negociadas. Só esse último caso é resultado do regateio entre as partes e está limitado especificamente a uma determinada instituição, aos mercados criadores de preços - autorreguláveis. ${ }^{8}$

Em 1977, Harry Pearson editou uma série de escritos dispersos de Polanyi, nos quais este aprofundava muitas das questões teóricas de Trade and market. Neste livro, intitulado The livelihood of man, ${ }^{9}$ Polanyi defende a sua abordagem institucional mais uma vez contrapondo-a a abordagens teleológicas que enunciam a economia de mercado, originária do comércio local de alimentos ou comércio de mercado, como objetivo natural de alguns três mil anos de desenvolvimento ocidental. No sentido institucional, o encontro de multidões de ofertantes e demandantes conduz a troca a equivalências fixas e não forma um mercado autorregulável - criador de preços. Mas, por outro lado, sempre que os elementos de mercado se combinam para formar um mecanismo de oferta-demanda-preço, nós falamos de mercados criadores de preço.

\section{O debate do mercado no antigo Oriente Próximo}

Embora uma história detalhada do estudo da economia do antigo Oriente Próximo seja uma tarefa difícil, é possível resumir suas linhas gerais da seguinte forma: uma primeira fase vai, aproximadamente, de 1920 (quando os primeiros modelos foram desenvolvidos) até por volta de 1960. Essa fase foi marcada por uma oposição entre visões centradas no Estado e visões "liberais", sendo a primeira visão dominante. As visões centradas no Estado eram especialmente prevalecentes na Alemanha e também na União Soviética (na forma do modo de produção escravista, então oficialmente adotada para todo o mundo antigo). As visões "liberais" prevaleceram no mundo de língua inglesa; uma segunda fase vai, aproximadamente, de 1960 até por volta de 1980 e foi marcada pelo impacto do "substantivismo" e do "neomar-

\footnotetext{
8 Idem, p. 311.

9 POLANYI, Karl. The livelihood of man. Nova York; São Francisco; Londres: Academic press, 1977.
} 
xismo" (com o modo de produção asiático), pelo uso mais explícito de modelos antropológicos e paralelos, pelo abandono de padrões evolucionistas universais e pela busca por traços propriamente do Oriente Próximo; finalmente, uma terceira, que ainda continua, é marcada pela crítica ao "substantivismo" e ao "neomarxismo" pela introdução da análise multifatorial (às vezes influenciada pela teoria dos sistemas) e a palavra-chave (e o conceito chave) de "complexidade", com o abandono de teorias gerais e de uma estrutura histórica a favor de valores permanentes e leis comportamentais. ${ }^{10}$

Uma grande parte dos historiadores, e inclusive os economistas, estima que a evolução das sociedades do antigo Oriente Próximo e o progresso de suas instituições de fato não dependem da economia nem das suas leis. Dependem menos ainda de uma economia de mercado, que não existia na Antiguidade, sendo uma realidade moderna, instalada e determinada por condições históricas específicas, por exemplo, o desenvolvimento tecnológico, ou o preço do trabalho. Outros historiadores e economistas, mas também antropólogos e sociólogos, por outro lado, consideram que as sociedades antigas, como as modernas e contemporâneas, eram dominadas na sua evolução pelo funcionamento de estruturas econômicas e de trocas que governavam a produção. Por razões simplesmente cronológicas, a história das sociedades do antigo Oriente Próximo tem sido tradicionalmente a disciplina em que começou a ser sistematicamente debatido, do ponto de vista antropológico e etnológico, o problema da primeira aparição da economia moderna, quer dizer, complexa e não primitiva. ${ }^{11}$

Um dos problemas que tornam difícil o avanço deste debate é o fato dos modelos mais importantes de interpretação da economia mesopotâmia terem sido elaborados e colocados em circulação em uma época em que a documentação, tanto arqueológica quanto epigráfica, no que tange a seus aspectos característicos principais, não era ainda, qualitativa e quantitativamente, suficientemente abundante para permitir verificá-la e pô-la a prova. Além disso, os modelos de interpretação da economia mesopotâmia devem levar em consideração as variações temporais e espaciais ao longo do desenvolvimento histórico da civilização mesopotâmia, que não se constitui

\footnotetext{
${ }^{10}$ LIVERANI, Mario. The near East: The Bronze Age. In: MANNING, Joseph Gilbert $\&$ MORRIS, Ian. The ancient economy. Evidence and models. Stanford, California: Stanford University Press, 2005, p. 56.

${ }^{11}$ MASETI-ROUAULT, Maria Grazia. Économie de redistribution et économie de marché au proche-Orient ancien. In: ROMAN, Yves \& DALAISON, Julie. L'économie antique, une économie de marché? Actes des deux tables rondes tênues à Lyon les 4 février et 30 novembre 2004. Paris: Soc. des Amis de J. Spon, De Boccard, 2008, p. 51-52.
} 
em uma unidade homogênea. Desenvolvimentos mercantis em certas localidades, em um dado período, não devem ser generalizados para todas as cidades-Estados, pois as formas de organização de mercados podem não ser as mesmas para outras localidades.

Estes primeiros modelos estão assim preocupados em definir a situação das origens mesmas da história, elaborando uma descrição da organização social e econômica das cidades-Estados mesopotâmias do início do terceiro milênio a. C. Os mais importantes foram fornecidos nos anos de 1950 por A. Deimel $^{12}$ e A. Falkenstein, ${ }^{13}$ seguidos por I. J. Gelb, ${ }_{r}^{14}$ assiriólogos que primeiro estudaram os arquivos cuneiformes provenientes das cidades sumérias de Uruk e de Lagash, testemunhas das atividades administrativas das instituições urbanas locais. Muito esquematicamente, a sociedade e o Estado mesopotâmios das origens são representados como uma comunidade dominada por grandes instituições, os templos e/ou palácio real, que operam nas cidades e permanecem proprietárias últimas das terras agrícolas, fonte primeira das atividades de produção. Estas instituições - e as elites que as representam - depois de terem recolhido as riquezas utilizadas para remunerar, pelas rações ou salários, as prestações pessoais dos serviços especializados, como o exército, os escribas ou os artesãos, redistribuem o restante da produção à população da cidade e do campo engajada no trabalho. Esta redistribuição é feita sobre uma base regular - registrada sistematicamente por uma burocracia e atestada na documentação cuneiforme -, necessária para a subsistência imediata. ${ }^{15}$ Segundo David Snell, a teoria templo-estado desenvolvida por Anton Deimel e Anna Schneider incorria em um erro grave, o de generalizar a partir de um único grupo de textos que derivavam de um templo e mostravam os interesses dos dirigentes do templo, ignorando a presença de um grupo de pessoas privadas que manipulavam riquezas. ${ }^{16}$ Há uma resistência em aceitar, nesse modelo, que as sociedades possam se organizar em uma forma de organização complexa sem adotar um modelo estatal. ${ }^{17}$

${ }_{12}$ Ver DEIMEL, A. Sumerische Tempelwirtschaft zur Urukaginas und seiner Vorgänger. Roma, 1931.

${ }^{13}$ Ver FALKENSTEIN, A. La cité-temple sumérienne. Cahiers d'histoire mondiale, v. 1, 1954, p. 784-814.

${ }^{14}$ Ver GELB, I. J. On the alleged temple and state economies in ancient Mesopotamia. In: Studi in Onore di Edoardo Volterra, v. 6, Milão, 1969, p. 137-154.

${ }^{15}$ Idem, p. 52.

${ }^{16}$ SNELL, David. Life in the ancient near East. New Haven; Londres: Yale University Press, 1997, p. 149.

${ }^{17}$ A partir da década de 1970, duas tendências se contrapõem ao modelo do templo-estado; uma enfatiza o papel da centralização política como elemento integrativo, com enfoque no sistema administrativo; e a outra confere maior importância aos particularismos e aos fatores históricos, com maior peso nos fatores econômicos e sociais, como a urbanização e a estratificação. 
Nesses modelos, que generalizam esta realidade para toda a Mesopotâmia, mas que se identificam mais com a Mesopotâmia meridional, não há lugar para o desenvolvimento de uma economia de mercado, e do mercado, com ausência de moeda e de dinheiro, assim como do capital. Não é mais questão de valor, de preço, nem de regulação de oferta e demanda, mesmo se a complexidade e o tamanho da organização burocrática, que localmente podia organizar dezenas de milhares de pessoas, fossem necessários para o estabelecimento de sistemas de equivalências para medir os diferentes produtos, por exemplo, entre a cevada/o inheiro/lã. O sistema que predominou foi a autarquia, cada grupo humano tendeu a produzir diretamente para suas necessidades. A agricultura cerealífera irrigada, de uma parte, e, de outra, a criação de ovinos e caprinos são em todas as épocas os pilares deste tipo de produção mesopotâmia. ${ }^{18}$ Fora os períodos de crise, muitas vezes devido aos problemas políticos, este sistema é praticamente inquestionável e indestrutível, e capaz de fornecer largos excedentes. ${ }^{19}$

Por outro lado, a situação geográfica da Mesopotâmia central e meridional torna absolutamente necessário para os estados locais o desenvolvimento de uma política de importação de materiais raros e preciosos, como os metais, as pedras duras ou a madeira, de regiões vizinhas, ou mesmo de muito longe. Essa dependência dos estados mesopotâmios frente à sua periferia pode justificar uma parte das atividades militares e de conquista bem como a formação de impérios desde o fim do terceiro milênio. Do ponto de vista econômico, ela provoca também a criação de um mercado, ou de um circuito comercial, com os países estrangeiros. Mas este mercado internacional, cuja existência é atestada pelas descobertas arqueológicas e pela documentação epigráfica, continua isolado em uma economia de redistribuição. Com efeito, estritamente limitado aos produtos raros, este tipo de mercado desenvolve as trocas segundo um princípio de dom e contradom entre as elites de países correspondentes, algumas vezes geridos por comerciantes.

\footnotetext{
Ver REDE, Marcelo. Da sociedade-templo à cidade-reino na antiga Mesopotâmia: Aspectos da transição. In: ALDROVANDI, Cibeli; KORMIKIARI, Maria Cristina; HIRATA, Elaine Farias. Estudos sobre o espaço na Antiguidade. São Paulo: Fapesp, 2011, p. 90.

${ }^{18}$ Ver LIVERANI, M. Il modo di produzioni. In: MOSCATI, S. (org.). L'Alba dela civiltà, vol II: L'economia. Turim, 1976, p. 1-126.

${ }^{19}$ MASETI-ROUAULT, Maria Grazia. Économie de redistribution et économie de marché au proche-Orient ancien. In: ROMAN, Yves \& DALAISON, Julie. L'économie antique, une économie de marché? Actes des deux tables rondes tênues à Lyon les 4 février et 30 novembre 2004. Paris: Soc. des Amis de J. Spon, De Boccard, 2008, p. 52-53.
} 
Controlados e algumas vezes organizados por tratados entre estados, não pode ser considerado em nenhum caso como um lugar de troca comercial, onde o valor das mercadorias seria avaliado pelas relações entre a oferta e a demanda. Na discussão dos preços, aparentemente têm mais peso os argumentos políticos e diplomáticos. ${ }^{20}$

É necessário observar, para além dessa explicação geral, desenvolvida por Maseti Rouault, as especificidades locais e a relação entre household e mercados, desenvolvidas por D. Snell. As relações entre as households e os mercados variavam muito ao longo do tempo. A household relativamente autossuficiente do antigo Oriente Próximo se mantinha ativa em momentos de estagnação econômica, e os governos eram originalmente households governadas por senhores ricos. Os governos estenderam sua exploração em um período histórico a alguns aspectos da maioria das outras famílias e alguns aspectos de mercados, mas nunca conseguiram eliminar todas as outras households ou controlar muitos mercados. Os governos podem ter sido originalmente households ampliadas, pois pagavam salários com a concessão de terras a soldados e funcionários. Na medida em que as households tiveram problemas em satisfazer suas necessidades, os mercados foram demandados e, quando estes não supriam tais demandas e desejos habituais, as households voltavam-se para si e supriam suas próprias necessidades, negligenciando outros desejos, não essenciais. Portanto, quando os mercados melhoram sua capacidade de atender as necessidades, as households, provavelmente lenta e timidamente em um primeiro momento, adaptam-se à disponibilidade de bens e serviços do exterior e buscam mais do que eles precisam dos mercados. Assim, se as households não mudam muito, os mercados, ao contrário, parecem ter sido voláteis. Se os mercados forem vistos como uma interação um sistema de informações, em que tudo está disponível para a compra, por um preço, em um local e sob determinadas condições -, é possível perceber como eles são mais suscetíveis aos fatores externos. O principal inibidor da atividade do mercado no antigo Oriente Próximo é, sem dúvida, a distância entre as households e as dificuldades de atravessar essa distância com mercadorias. Além disso, as guerras afetaram muito mais os mercados do que as households. Daí a instabilidade social do mercado. ${ }^{21}$

Nos primeiros períodos do antigo Oriente Próximo, não temos dados sobre os mercados de trabalho, e trabalhadores assalariados são raramente

\footnotetext{
${ }^{20}$ Idem.

${ }^{21}$ SNELL, David. Life in the ancient near East. New Haven; Londres: Yale University Press, 1997, p. $156-158$.
} 
comprovados na documentação antes do período de Ur III (2112-2004 a. C.) quando, então, eles se tornam bastante comuns. Isso poderia significar que os mercados eram fracos, ou que as organizações com acesso à escrita não contratavam estranhos ou não consideravam tal contratação digna de registro. Porém, não há período em que não tenha havido mercado ou em que as households tenham se voltado para os mercados de todos os bens e serviços que necessitavam e desejavam. Não houve tal pureza, no passado, como não existe em nenhum momento. ${ }^{22}$

\section{Polanyi e o mercado na Mesopotâmia}

Os dados concernentes à civilização mesopotâmia utilizados por K. Polanyi foram colocados a sua disposição por seus colegas do Instituto Oriental da Universidade de Chicago e, notadamente, por L. Oppenheim. Estes lhe serão úteis para fundar a teoria econômica da não existência do mercado criador de preços, da moeda e a regulação dos preços relativa à oferta e à demanda no mundo antigo. A fim de provar de maneira indiscutível a validade de seu modelo da redistribuição/reciprocidade/troca, ele escolheu como exemplo a sociedade da época de Hamurabi da Babilônia do início do segundo milênio a. C., ao Bronze médio II (2750-2600 a. C.), assim como o comércio realizado dois séculos antes por mercadores assírios estabelecidos na Anatólia. Ele os utiliza como exemplos "históricos" de trocas em uma situação sem mercado, sem riscos e sem moeda. Se a sociedade mesopotâmia não tinha mercado, então sua economia era distributiva: as trocas ainda eram dirigidas pelo princípio da reciprocidade, fóssil das relações humanas mais antigas. A ausência de uma economia de mercado é demonstrada pela argumentação, histórica e arqueológica, de não existência dos lugares de mercado, ausentes no tecido urbano e arquitetural das cidades orientais antigas. Ele estima também que a documentação escrita cuneiforme não fornece exemplos de transações comerciais nem de variações significativas dos preços, o que seria de se esperar em uma economia de mercado. Portanto, não há nada que pudesse se assemelhar a um sistema de mercado. O que se vê na Babilônia é um intercâmbio sem mercado, diferente deste no que se refere às pessoas envolvidas no intercâmbio, aos bens, aos preços e em relação à natureza da atividade do intercâmbio. Os mercadores assírios do karum (porto) de Kane-

\footnotetext{
${ }^{22}$ Idem, p. 158.
} 
che, por exemplo, não eram pessoas que ganhavam a vida com ganhos derivados das compras e vendas, das diferenças de preços na transação. Eram mercadores por status, em virtude de seu nascimento, de uma aprendizagem longínqua ou por designação. A menos que a designação fosse acompanhada de uma concessão substancial de terra, suas receitas derivavam da venda de bens, sobre a qual ganhavam uma comissão. Os preços tomavam a forma de equivalências estabelecidas pela autoridade de um costume, um estatuto, um edito. Presumia-se que as necessidades vitais estavam submetidas por equivalências permanentes. Na realidade, experimentavam mudanças, em longo prazo, com os mesmos métodos pelos quais foram estabelecidos. Isto não afetava a receita do mercador, que não dependia das diferenças de preços. ${ }^{23}$

A diferença fundamental entre o comércio administrado e o comércio de mercado reside na ausência de riscos para os comerciantes, tanto no relativo às expectativas dos preços quanto à possível insolvência do devedor. Não há perdas pela flutuação de preços.

Polanyi enumera algumas características conhecidas das trocas realizadas por meio do karum: nenhuma venda que não seja no local; o mercador recebe seu contingente de produtos contra uma fiança pelo valor destes; as obrigações para com terceiros devem ser registradas ante a autoridade competente, a cidade, o karum ou o palácio; assim, por princípio, os poderes públicos garantiam todas as obrigações; finalmente, os poderes públicos não aceitavam nenhum risco, pois rechaçam as obrigações que não oferecem segurança. Tudo isso explica porque não se produz nenhum pagamento de dívidas; porque as sentenças de arbitragem se executam sem necessidade de coação; porque um requisito para comerciar é o pertencimento ao karum e uma boa reputação ante a cidade; porque não se exigem depósitos para assegurar o pagamento; porque não se perde nunca o empréstimo livre de interesse que o empregado utiliza para comercializar por conta própria; porque nos negócios só se produzem ganhos e não perdas. ${ }^{24}$

As atividades deste comércio administrado são qualificadas de disposicionais, nas quais os comerciantes atuavam dentro do marco de uma organização governamental e uma rede de instituições oficiais e semioficiais que lhes davam garantias por meio de normas legais. Não obstante, as transações privadas não eram proibidas, na medida em que as normas legais tratavam da separação institucional das disposições comerciais relativas aos negócios

\footnotetext{
23 POLANYI, Karl, op. cit., p. 66-68.

${ }^{24}$ Idem, p. 70-71.
} 
públicos com respeito às transações privadas. O mercador atuava em virtude de seus atributos públicos para negociar o cobre, manejando contingente do governo ou à margem de suas atividades públicas, privadamente. Finalmente, Polanyi afirma que o tamkarum é um comissário público. Segundo o caso e a situação, seu papel era adiantar honorários ou outros gastos pequenos, aceitar fianças, servir de intermediário nas compras de bens da cidade pelo comerciante e na entrega de bens à cidade por conta do mercador, facilitar o transporte aceitando responsabilizar-se pelo dinheiro e bens encomendados. O tamkarum não recebia nenhuma receita pelos negócios em que intervinha, ainda que seja possível que cobrasse pequenos honorários aos mercadores de acordo com uma escala fixa. Seu sustento estava assegurado pela propriedade das terras que se lhe adjudicavam ao tomar posse do cargo.

\section{A crítica formalista}

Boa parte das conclusões de Polanyi sobre a Mesopotâmia vem sendo questionada tanto quanto aos princípios, quanto às informações que envolvem a arqueologia. Gledhill e Larsen contestam Polanyi quanto à inexistência de mercados na Mesopotâmia. A ausência de espaços abertos nas cidades escavadas não se sustenta, visto que nem todas as cidades foram escavadas e os portões da entrada das cidades, muitas vezes, parecem ter funcionado como a ágora grega. O conceito e o papel do karum são revistos à luz de novas descobertas. Segundo os autores, essa palavra, originalmente, denotava um lugar de ancoragem e, posteriormente, se constituiu em uma comunidade de mercadores que viviam no porto. O karum assírio de Kaneche era, segundo as evidências, um típico assentamento de casas privadas e lojas habitadas pertencentes a mercadores. Em geral, o karum babilônico antigo era uma comunidade de mercadores da cidade, com caráter corporativo e até um aparato administrativo e judicial separado. Referências da relação entre o palácio e o karum podem ser encontradas em um decreto real publicado no período babilônico tardio. O palácio podia aplicar metade do capital nas operações realizadas no karum. Os mercadores eram responsáveis pela coleta de impostos proveniente dos contribuintes que se utilizavam diretamente das atividades comerciais. O palácio usava os mercadores independentes do karum como agentes, porque seu objetivo era evitar a administração direta da produção, do comércio e da supervisão e forçar os comerciantes a correrem os riscos do negócio. Portanto, esses comerciantes eram livres para acumular riquezas. Além disso, estudos dos preços e salários na antiga Babilônia mostram um padrão substancial de flutuações nos preços das mercadorias bá- 
sicas, o que reflete provavelmente desenvolvimentos no padrão econômico da região como um todo. ${ }^{25}$ Portanto, diferente de Polanyi, esse estudo revela que o mercado operava com lucros e perdas e que a liberdade para acumular riquezas era uma condição para que eles assumissem os riscos dos negócios.

A crítica mais contundente aos trabalhos de Polanyi partiu do americano Morris Silver. Seus trabalhos sobre o antigo Oriente Próximo têm sido uma referência para os formalistas e também para os críticos do formalismo. Em 1983, Silver escreveu um artigo no periódico americano The Journal of Economic History intitulado "Karl Polanyi and markets in the ancient near East: the challenge of the evidence", no qual tece uma série de observações críticas ao trabalho de Polanyi. Neste ensaio, Silver contesta a posição de Polanyi ao confrontar suas asserções factuais sobre as economias do antigo Oriente Próximo com a evidência disponível.

Morris Silver contesta a asserção de Polanyi de que o comércio estrangeiro foi conduzido por um tipo de comércio intitulado "portos de comércio", em que os preços eram determinados por tratados, não por oferta e demanda. A especificação de preços, em particular em contratos de longos prazos, serve para limitar a incerteza e oportunismo ou para preencher lacunas nos mercados. Tratados governamentais, uma forma de contrato, também podiam ser empregados, todavia ainda se reconheciam as forças da oferta e da demanda. Há ampla evidência de tratados comerciais e correspondência real tratando de assuntos relacionados ao comércio. Para tomar um exemplo mencionado por Polanyi, cartas escavadas na Capadócia, na Anatólia central (o nome moderno da Turquia asiática), revelam que, no início do segundo milênio, governantes forneciam segurança junto às rotas de caravanas a partir de Assíria, uma região ao norte da Mesopotâmia. Os mercadores assírios pagavam impostos sobre as mercadorias que eles levavam em troca de segurança. Em uma carta datada do século XVIII a. C., um governante queixa-se com seu colega assírio sobre a quantia insultante de estanho que ele tinha recebido por seus cavalos, o que dificilmente soa como um comércio com preços administrados. ${ }^{26}$

\footnotetext{
${ }^{25}$ GLEDHILL, John $\mathcal{E}$ LARSEN, Mogens. The Polanyi paradigm and a dynamic analysis of archaic states. In: RENFREW, Colin; ROWLANDS, Michael; SEGRAVES, Barbara Abbott (ed.). Theory and explanation in archaeology. Nova York: Academic Press, 1982, p. 204-208.

${ }^{26}$ SILVER, Morris. Karl Polanyi and markets in the ancient near East: The challenge of the evidence. The Journal of Economic History, v. 43, no 4, 1983, p. 795-829, especialmente, p. 796-797. Disponível em: http://dx.doi.org/10.1017/S002205070003076X.
} 
A evidência sobre a formação de preço no posto comercial assírio na Capadócia é totalmente consistente com a operação de forças de mercado do tipo comum. Os milhares de documentos comerciais provenientes do posto referem-se a trocas com demandas ou ofertas das principais mercadorias importadas (estanho e têxteis feitos de lã), os efeitos de sazonalidade e emergência, e mudanças em registro de preços. Mudanças de preços, incluindo mais de 20 por cento de mudança no preço do estanho durante um curto período, demonstram a inconsistência da posição de Polanyi. Um texto datado do reinado de Hammurabi (1792-1750 a. C.) consigna uma grande quantidade de tinta para venda em um reino vizinho "de acordo com o mercado (de preço)", e um tanto mais tarde, na cidade de Nuzi, no leste da Assíria, especifica que um mercador devolvia o "preço" da mercadoria que ele vende no estrangeiro. ${ }^{27}$

Com o fito de demonstrar que o mercado estava presente na civilização mesopotâmia, Silver apresenta alguns exemplos da evidência de variações sazonais nos preços de grão na Mesopotâmia. Segundo o autor, o modelo sazonal é o resultado de mudanças na curva da oferta do grão devido a evidentes custos de estocagem. Empréstimos de grãos geralmente eram feitos antes da colheita (em época de semeadura ou depois), quando os preços estavam relativamente altos, e reembolsados logo depois da colheita, quando os preços estavam relativamente baixos. É impossível dizer se o registro de um carregamento de grão representa uma especulação comercial, pagamento de impostos ou algum outro propósito. Todavia, os textos que datam do início do terceiro milênio também se referem ao sumério lú-se-sa-as (acadiano muqallû) que quer dizer "quem o torrou e vendeu no mercado". Um documento proveniente do início do segundo milênio, achado no posto comercial assírio na Anatólia, atesta a compra por comerciantes de quantidades substanciais de cevada e trigo revendidos mediante um lucro. Empréstimos de grãos eram frequentemente feitos por indivíduos descritos como "mercadores" na primeira metade do segundo milênio, embora o significado da palavra em si seja motivo de discussão. Outros textos revelam celeiros fazendo negócio com o público em geral declarando serem privadamente possuídos ou pelo menos sem nenhuma ligação aparente com o palácio ou templo. ${ }^{28}$

Conhecemos os nomes e muito sobre as atividades de vários emprestadores profissionais de dinheiro importantes que operaram durante vários séculos na Babilônia a partir do final do terceiro até a primeira metade do

\footnotetext{
${ }^{27}$ Idem, p. 797.

${ }^{28}$ Ibidem, p. 799-801.
} 
segundo milênio. De fato, a parte inicial do segundo milênio fornece numerosos contratos de empréstimos de uma natureza inteiramente comercial. Nas tabuletas da Capadócia do início do segundo milênio, os propósitos registrados de empréstimos para assírios correspondiam a objetivos comerciais, tais como compras de mercadorias e viagens comerciais. Documentos provenientes de Nuzi, no leste da Assíria, demonstram que emprestadores privados faziam empréstimos com juros para "empreendimentos comerciais" para mercadores. Contratos do século VII a. C. escavados na Assíria raramente especificam o propósito de um empréstimo, mas, em um caso, a compra de burros está envolvida e, em outro, o mutuário parece ser um líder de caravana comercializando grão. Documentos babilônios quase da mesma época não somente registram empréstimos comerciais (ou investimentos), mas frequentemente especificam o tipo de negócio em um empreendimento comercial. ${ }^{29}$

Durante o século XIX a. C., empreendimentos babilônios davam fundos para mercadores que participavam no comércio do golfo Pérsico. Similarmente, as casas ou empresas mercantis envolvidas no comércio assírio com a Capadócia eram financiadas por meio de parcerias de longo prazo chamadas transações naruqqu (literalmente, "saque"). Um contrato mostra o envolvimento de somas substanciais, ficando o próprio comerciante com um terço do lucro ganho durante os doze anos de duração do acordo e os outros contribuintes para o naruqqu recebiam o restante do lucro. Os investidores ficavam excluídos de uma parte no lucro do empreendimento, se eles retirassem seus fundos antes da expiração do contrato, mas era permitido vender a parte deles do naruqqu para terceiros. Além de crédito, casas bancárias e negociabilidade, o mercado de empréstimo comercial ampliou-se por recorrer a fiança ou garantia de terceiros de reembolso. Contratos de fiança são bem conhecidos do século VII ao VI a. C., mas também são achados muito no início do segundo milênio em Nuzi na Assíria e na Anatólia. Na Assíria do século XIV a. C., tabuletas de título podiam ser compradas e vendidas no mercado, com o comprador obtendo o direito à demanda e tomar posse. ${ }^{30}$

Um texto proveniente do sul da Babilônia registra a posse de terra no $\mathrm{ka} \mathbf{a}^{-}$ rum e outro concerne a uma casa no karum de peixe; vários documentos referem-se à venda de grão, lã e escravos no karum. O termo "estradas" (acadiano $s \bar{u} q u)$, muitas vezes achado nos documentos, também conota um mercado. Textos oriundos da primeira metade do terceiro milênio falam de mercadorias

\footnotetext{
${ }^{29}$ Ibidem, p. 801.

${ }^{30}$ Ibidem, p. 804-805.
} 
"na rua"; tabuletas provenientes da primeira metade do segundo milênio referem-se ao suqšimātim ou "rua comercial". Em um texto oriundo da Assíria do século VII a. C., camelos árabes capturados são vendidos na entrada de mercado (inabābmah̄iri). Empréstimos também eram reembolsados "no mercado" ${ }^{31}$

Em relação aos comerciantes, a evidência não demonstra que o comércio era monopolizado pelo governante. Segundo Silver, os mercadores que comercializavam na Capadócia eram basicamente empresários privados, não funcionários do governo. Esse ponto é ilustrado por uma carta mandada por um grande mercador queixando-se de que ele está perdendo um negócio de lucro por causa de atrasos em obter um empréstimo necessário para financiar um empreendimento comercial. Mercadores mandavam suas mercadorias para Anatólia sem a garantia de certo preço em adiantamento. Quase ao mesmo tempo, por outro lado, o comércio do golfo Pérsico com Tilmun (provavelmente a ilha de Bahrain) estava nas mãos de mercadores que se intitulavam ālik Tilmun (melhor traduzido como "empreendedores de Tilmun"). O ālik Tilmun, como aqueles que consignavam mercadorias para a Capadócia, eram certamente aqueles que corriam riscos. Aparentemente, eles eram financiados por investidores privados designados a comprar o cobre a um preço contratualmente especificado, mas não responsável por quaisquer perdas do empreendimento. ${ }^{32}$

Durante o começo do segundo milênio, há pouca evidência de uma conexão entre tamkārum e Estado. $\mathrm{O}$ antigo Oriente Próximo tinha conhecimento sobre mercadores ricos que não eram meramente agentes do Estado. No comércio assírio com a Capadócia, as maiores firmas ou casas pertenciam ao karum. Algumas firmas comerciais babilônicas usavam agentes de independência variada. Além disso, o comércio assírio do início do segundo milênio não conhecia somente grandes mercadores pertencendo ao estabelecimento comercial, mas pequenos empresários que atuavam como transportadores e agentes juniores. Esses comerciantes "de classe média" tiveram êxito em transformar-se em membros do karum.

Para Maseti-Rouault, a topografia urbana antiga comporta lugares de mercado como a Babilônia. O léxico babilônico exprimiu essa realidade, tanto de um ponto de vista estritamente geográfico quanto de um ponto de vista metafórico, indicando diferentes processos econômicos relativos às trocas. A documentação cuneiforme ilustra doravante, de uma maneira

\footnotetext{
${ }^{31}$ Ibidem, p. 815-816.

32 Ibidem, p. 823-824.
} 
convincente, não somente a variação das taxas de interesse, mas também a formação, desde o fim do terceiro milênio, de uma nova categoria social que representa um papel econômico diferente e específico. É a extensão e a complexidade da administração das unidades de produção - propriedades dos templos e dos palácios - que acabaram por gerar, desde a metade do terceiro milênio, uma nova categoria de administradores. Os burocratas que trabalharam para sua instituição como funcionários se transformam progressivamente em empreiteiros e em mercadores. Garantir à instituição ou ao Estado uma anuidade fixa, um fluxo constante, fornecidos pelas diferentes unidades, é a função desses homens que gerenciam os negócios na perspectiva de obter uma vantagem econômica pessoal e, enfim, enriquecer. Eles especulam assim sobre a produção, exercendo uma pressão cada vez mais importante sobre a população que trabalha na ou pela instituição, que lhes deve agora uma cota de produção. Os limites parecem impostos unicamente pelo Estado e pelos reis, que, no início do segundo milênio, intervêm regularmente, pelos editos de justiça, nas relações entre estes empreiteiros e banqueiros e seus administrados. Os reis anulam as dívidas contraídas pelos agricultores frente aos empreiteiros e banqueiros, impedindo, assim, ao menos parcialmente, a venda de campos e casas submetidas a hipotecas e sua passagem ao patrimônio pessoal do credor. A documentação textual mostra que esses empreiteiros tinham uma mentalidade nova: funcionavam e trabalhavam sobre uma base de busca de lucros e de enriquecimento pessoal. Eles aceitavam correr os riscos, mas sabiam diversificar seus investimentos a fim de limitar as eventuais consequências negativas. Os exemplos mais claros desta nova função e categoria social são os mercadores assírios instalados na Capadócia, em Kaneche. ${ }^{33}$

\section{A resposta substantivista}

A teoria de Polanyi - sobretudo no seu aspecto descritivo do sistema de redistribuição - resistiu bravamente a todos os ataques que lhes foram dirigidos por essas novas realidades e descobertas epigráficas. Ainda hoje ela encontra um grande sucesso frente aos assiriólogos especialistas dos textos econômicos e administrativos, e também historiadores, talvez na medida em que ela corresponda a uma visão integrativa de todos os aspectos da cultura mesopotâmia.

35 MASETI-ROUAULT, Maria Grazia, op. cit., p. 55-56. 
Anne Mayhew, Walter Neale e David Tandy responderam a Morris Silver concordando com este que houve mudanças de preço no antigo Oriente Próximo, mas não concordam que tais mudanças tenham gerado um mercado criador de preços. Além disso, afirmam que Silver não prova que as quantidades de mercadorias ofertadas dependiam dos preços das mercadorias ou que o padrão material de vida de pessoas dependia dos preços que eles recebiam para contribuir para a produção de mercadorias. Portanto, as mudanças de preço de alimentos e outros itens cotidianos em condições de fome, sem a comprovação de que estes variavam determinados por lucros ou despesas de mercado é uma evidência de que tais variações não eram determinadas por um mercado criador de preços. ${ }^{34}$

Johannes Renger é, sem dúvida, o assiriólogo que mais investiu na aplicação dos modelos polanyianos na economia assírio-babilônia, e que continua a ser o defensor mais fiel da teoria original da redistribuição. Ele a modificou e a alargou a fim de que ela pudesse inteirar-se de toda a documentação nova. Ele insiste que nem Oppenheim, nem Polanyi excluíram a possibilidade de existência do mercado, se este termo identifica simplesmente uma forma qualquer de economia. Por outro lado, eles rejeitaram a existência, no mundo oriental, de uma economia de mercado e de um mercado pré-capitalista, que se regesse de maneira mecânica e autônoma a partir das relações entre oferta, demanda e preço.

Em dois artigos, Renger apresenta seus argumentos sobre a economia e a sociedade da Mesopotâmia. Central em seus trabalhos é a descrição das atividades econômicas como parte das estruturas e processos característicos de uma economia particular. Tais atividades - as trocas, o comércio e os comerciantes - são contextualizadas na estrutura econômica da sociedade mesopotâmia.

No artigo intitulado "Trade and market in the ancient near East. Theoretical and factual implications", publicado em 2003, no livro Mercanti e política nel mondo antico, organizado por Carlo Zaccagnini, Renger afirma que os elementos estruturais dominantes da vida econômica e social na antiga Mesopotâmia podem ser percebidos na base de uma dicotomia entre a economia de oikos do terceiro milênio e uma economia caracterizada por formas tributárias a partir do segundo milênio em diante.

\footnotetext{
${ }^{34}$ TANDY, David $\mathcal{E}$ NEALE, Walter. Karl Polanyi's distinctive approach to social analysis and the case of ancient Greece: ideas, criticism, consequences. In: DUNCAN, Colin \& TANDY, David. From political economy to anthropology. Situating economic life in past societies. Montreal: Black Rose Books, 1994, p. 129-131.
} 
A maioria das economias antigas é de certo modo tripartida, isto é, baseada, em primeiro lugar, em agricultura e criação de animais, em segundo, na produção de mercadorias fabricadas, e em terceiro, em diferentes formas de troca das mercadorias. Como é indiscutível, a maioria das economias de qualquer civilização antiga é baseada primeiramente em agricultura e criação de animais. Ambos estão interligados em um modo sistemático. Mercadorias fabricadas feitas dos materiais resultantes da produção agrícola e da criação de animais bem como aquelas vindas da exploração de recursos naturais são mais uma parte integral de tal economia. A troca interna e o comércio de longa distância representam um terceiro elemento de tal economia. A produção de mercadorias fabricadas por artífices ou artesãos, bem como todas as formas de troca e comércio representam - em termos quantitativos - somente um papel suplementar dentro de tal sistema econômico. Economias antigas baseadas na agricultura e na criação de animais são economias de subsistência. Portanto, é necessário indagar como os produtores tomam parte nos resultados de seu trabalho e como eles têm acesso ao que eles têm produzido? ${ }^{35}$

A economia do final do terceiro milênio é caracterizada por um tipo de economia que tem sido denominada economia do oikos, como uma household autárquica. Todas as mercadorias necessárias e consumidas pelos membros da household são produzidas dentro da household. Somente umas pouquíssimas mercadorias e objetos têm de vir de fora - metais e outros materiais raros, bem como objetos prestigiosos. O tamanho do oikos de um governante é idêntico em termos espaciais ao tamanho de seu reino. Max Weber o denominou de oikos patrimonial, um tipo de patrimônio de Estado. Portanto, as estruturas da sociedade e da economia na baixa Mesopotâmia, isto é, na antiga Suméria, que fica muito ao sul, no atual Iraque, a partir do final do quarto milênio - como revelado pelos arquivos administrativos de Uruk, contendo os registros mais antigos da humanidade - até aproximadamente 2500 a. C. podem ser descritas em termos de uma economia do oikos.

A partir do início do segundo milênio, a economia do oikos do terceiro milênio foi gradualmente substituída por formas tributárias. ${ }^{36} \mathrm{Na}$ economia tributária, as atividades econômicas eram individualizadas. As necessidades

\footnotetext{
35 RENGER, Johannes. Trade and market in the ancient near East. Theoretical and factual implications. In: ZACCAGNINI, Carlo (ed.). Mercanti e politica nel mondo antico. Roma: L'Erma di Bretschneider, 2003, p. 16-17.

36 Tributário - um termo cunhado por Pierre Briant - descreve uma economia na qual o palácio e os templos se despojaram de grande parte da atividade econômica.
} 
do palácio - ou de qualquer outra household institucional - não eram satisfeitas por meio da produção dentro de uma household autossustentável. A produção era entregue a outros, isto é, privilegiada a indivíduos que tinham imediatamente de entregar parte dos resultados de seus esforços produtivos para a instituição em forma de impostos ou tributos. A emergência e a formação da economia tributária aconteceram gradualmente e com diferenças significativas entre o norte e o sul da Babilônia, isto é, os reinos da Babilônia, Isin e Larsa.

Dentre as atividades econômicas despojadas de instituições centrais se encontra a coleta de impostos e tributos; e as atividades de comerciantes de longa distância organizadas como uma atividade empresarial. Os elementos típicos de tal atividade empresarial são os seguintes: o palácio incumbe um empresário de uma atividade econômica particular, e este assume os riscos; a relação entre palácio e empresário é estabelecida em um contrato. O contrato consiste de um número de cláusulas que regulam as obrigações do empresário de desembolsar ou cumprir seu contrato nos termos da época, e da quantia a ser paga que é fixada antecipadamente em termos absolutos ou fixada proporcionalmente em relação ao total da colheita determinada por estimativa logo antes da colheita. ${ }^{37}$

Durante o período da antiga Babilônia - isto é, mais ou menos entre os séculos XVIII e XVII a. C. - as atividades dos mercadores e empresários estavam intimamente ligadas aos interesses e necessidades das households institucionais, na maioria das vezes, do palácio. Os mercadores eram organizados como um grupo ou colegiado de forma regional, ligados com o distrito portuário do karum. Nessas circunstâncias, não há muito espaço para um mercado nos moldes da ágora ateniense. Os modelos mesopotâmicos de abastecimento de alimento para a população depõem contra a existência de um mercado por meio do qual todos os alimentos necessários para o sustento de alguém poderiam ser obtidos. O fato de que os artífices estavam integrados às households institucionais na economia de oikos, bem como na economia tributária do período da antiga Babilônia tem um impacto sobre as necessidades de troca. As mercadorias necessárias dentro da household institucional eram produzidas interiormente. Até no que diz respeito às households privadas, particulares, muito do que era necessário era produzido ali. Uma situação diferente é observada nos centros urbanos durante as épocas da neo-Babilônia (sexto/ quinto séculos a. C.): a produção de mercadorias e os serviços produzidos

\footnotetext{
37 RENGER, Johannes, op. cit., p. 21.
} 
por artífices e artesãos parecem estar acontecendo em duas esferas distintas: por um lado, os artífices estão ligados às grandes households dos templos; por outro lado, escravos treinados como artífices especializados, trabalhando em suas próprias oficinas, são obrigados a pagar uma taxa anual a seus mestres. Os artífices escravos obviamente produziam mercadorias para uso geral da população urbana. Os artífices ligados às grandes households dos templos serviam predominantemente às instituições para as quais eles estavam ligados. Mas é concebível que eles também produzissem sozinhos para "clientes" particulares, um padrão do período de Ur III.

O entendimento dessa estrutura é fundamental para a compreensão da contundente crítica que Renger tece a Morris Silver no artigo intitulado "On economic structures in ancient Mesopotamia", publicado no periódico Orientalia em 1994. Renger esquadrinhou os trabalhos de Silver, apontou suas falhas e esboçou outra perspectiva, de matriz polanyiana, não voltada para a descrição de simples fatos econômicos, mas para a compreensão da economia antiga como sistemas econômicos complexos e integrados, ou seja, concebidos como um todo.

Renger questiona o papel do mercado como um elemento estrutural da economia da antiga Mesopotâmia. Quando Silver fala de mercados de crédito, escravidão e terra, suas palavras transmitem a impressão de uma economia particularmente similar à nossa própria. Mas, segundo Renger, Silver não consegue demonstrar que o trabalho escravo constituiu um fator quantitativamente decisivo no processo de produção na antiga Mesopotâmia. Ele não mostra que ali existiu um mercado de terra agrícola como o de meios básicos de produção. E suas observações sobre mercado de investimento e crédito não são convincentes. O que não se compreende em seus argumentos sobre a existência de mercados é um claro relato ou explicação dos critérios que poderiam servir como prova para existência deles. É um método completamente inaceitável de pesquisa histórica assumir que uma simples referência a algo vendido ou comprado, a um contrato de pagamento ou a um empréstimo seja evidência suficiente para crédito, trabalho, terra ou mercados de mercadorias. É necessário dar atenção ao contexto político, social e histórico ou investigar, por exemplo, o papel quantitativo desses fenômenos dentro do sistema econômico todo de um dado período. Deve ser provado que os mercados existiram como reflexos de um processo instituí- 
do; que eram tangíveis em termos pessoal, espacial e temporal; e que refletiam um elemento estrutural viável da economia da antiga Mesopotâmia. ${ }^{38}$

Uma pesquisa sobre a apropriação do espaço e sua articulação com o contexto social, econômico e político no sul babilônico, na cidade de Larsa, efetuada por meio dos registros de uma família que viveu entre os séculos XIX e XVIII a. C., levada a cabo por Marcelo Rede, demonstrou que o controle do espaço não pode se concentrar apenas na identificação dos agentes de controle da terra, deixando de lado as práticas de apropriação e as relações que mantêm com os demais domínios da vida social. Em vez de um mercado impessoal, observa-se, nos negócios imobiliários em Larsa, que os laços de parentesco ou vizinhança constituem uma condição essencial para a realização das trocas entre os grupos. As relações de parentesco estavam presentes nos arranjos implicados pelas alienações. Além disso, uma parte considerável das transações imobiliárias desenvolveu-se no seio de uma rede de vizinhança. Portanto, as transferências de terrenos desenvolveramse no quadro das relações de proximidade. ${ }^{39}$

O rei intervinha alterando o modo de contato entre as pessoas próximas, obrigando parentes e vizinhos a redefinirem suas interações. A finalidade dos decretos reais era a recomposição de laços de proximidade no interior de grupos sociais delimitados e não o reequilíbrio social de um mercado institucionalizado. O palácio se precavia contra os efeitos de uma tensão social originada no desequilíbrio das relações de parentesco e de vizinhança, além de buscar limitar a influência da elite urbana que se beneficiava com a concentração fundiária. Daí os decretos recaírem sobre os terrenos urbanos. Não se tratava de renúncia tributária, pois o impacto econômico das intervenções era pequeno no universo imobiliário. ${ }^{40}$

Rede concluiu que os agentes econômicos que participavam do processo de circulação de imóveis em Larsa como compradores não atuavam como vendedores. Não se sustenta a visão de uma classe mercantil que teria feito da negociação de terrenos uma fonte de renda e lucro. Junto a isso, percebe-se um comportamento aquisitivo cumulativo em espaços contíguos de terrenos negociados em uma região marcada socialmente por relações de parentesco e vizinhança. Os estudos estatísticos dos contratos de compra

\footnotetext{
${ }^{38}$ RENGER, Johannes. On economic structures in ancient Mesopotamia. Orientalia, n. 63, 1994, p. 157-208, especificamente, p. 174-175.

39 REDE, Marcelo. Família e patrimônio na Mesopotâmia. Rio de Janeiro: Mauad X, 2007, p. 190.

${ }^{40}$ Idem, p. 191-192.
} 
e venda revelaram, no tocante às oscilações de valores mais acentuados para os terrenos urbanos, um comportamento mais afetado por consumo conspícuo, uma disposição à divisão dos lotes por parte dos vendedores, que também tendiam a vender uma quantidade mais limitada de superfície quando os preços subiam. Portanto, um circuito bem diferente dos mercados imobiliários modernos. ${ }^{41}$

O papel e as formas de crédito em uma dada economia podem servir como um importante indicador da complexidade e sofisticação prevalecente em tal sistema econômico. Para Polanyi, o crédito representou um papel diferente na Antiguidade, pois não era regido pelos mercados criadores de preços, no qual sua emergência assume "funções de um novo caráter". A discordância de Silver da posição de Polanyi gira em torno da questão da existência ou não de empréstimos comerciais não agrícolas. Contudo, o problema parece ser mais complicado. Para Renger, a origem de empréstimos e crédito em uma economia camponesa, isto é, uma economia determinada por produção de subsistência, é diferente das sociedades modernas. O crédito sob tais condições sociais específicas pode também ser concebido como parte de um sistema de reciprocidade. Os princípios de solidariedade tradicional exigiam assistência mútua observando serviços necessários ou mercadorias. Empréstimos e serviços, certamente, estão acoplados à obrigação de ação eventual recíproca, ou por restituição em espécie do que era recebido ou por substituição. Visto que a reciprocidade é somente esperada depois de algum tempo, poder-se-ia descrever a situação inteira em termos econômicos (modernos) como crédito. Parece, contudo, que uma análise só em termos econômicos não é adequada para explicar as implicações sociais fundamentais.

O crédito na Mesopotâmia antiga é em geral de dois tipos: crédito dado em espécie, isto é, na forma de objetos tangíveis, mercadorias ou matérias primas (incluindo metal); e o crédito de mercadorias ou matérias primas de modo fictício, dado em provisão para reembolsar em espécie o que era de modo fictício dado. As relações de crédito podiam ser estabelecidas entre indivíduos, um como credor, outro como devedor; entre indivíduos e households institucionais (o último geralmente era o credor); e finalmente entre duas instituições. O tipo de crédito e sua forma, que determinavam as relações de crédito entre credor e devedor - sejam eles indivíduos ou instituições -, dependiam das circunstâncias do empréstimo. É a formulação altamente abstrata de crédito ou

\footnotetext{
${ }^{41}$ Ibidem, p. 194-195.
} 
documentos de empréstimo que os tornam facilmente adaptáveis a uma ampla variedade de circunstâncias, mas também dificultam o reconhecimento de suas causas e consequências básicas. ${ }^{42}$

Empréstimos de consumo ou "de colheita" são fundamentais em sociedades agrícolas que contam com a produção de subsistência. Em sistemas redistributivos, tais empréstimos de consumo são necessários na medida em que boa parte da população está direta e completamente sob os cuidados das households institucionais. Contudo, em tempos de dificuldades, as pessoas que estavam à margem do sistema redistributivo podiam virar-se para o templo (geralmente em Ur III) ou para indivíduos privados (melhor atestado para o período babilônico antigo) no intuito de pedir empréstimos de colheita ou de consumo. Assim, o fato de que os templos bem como os indivíduos concediam empréstimos não justifica discordar da afirmação de Polanyi de que, no Estado arcaico, o templo e o palácio eram os principais provedores de crédito de colheita. Também sabemos que empréstimos de colheita dados pelo templo ou palácio muitas vezes não eram registrados em contratos legais, mas por meio do sistema de registro contábil das households institucionais. Pode-se chamar a atenção nessa ligação para a obrigação (ideologicamente determinada) dos templos ampararem os mais necessitados. Um exemplo notável que vai além de atos efêmeros de assistência para a necessidade é a instituição a.ru.a. Aqueles incapazes de sobreviver por si sós ou por meio das famílias em apuros podiam dedicar-se (a.ru) ou dedicar membros de sua família a um templo que os incorporaria dentro de seu pessoal e proveria a subsistência deles. Desse modo, a concessão de empréstimos de colheita pelos templos parece ter o mesmo background ideologicamente motivado: cuidar dos mais fracos.

Há ampla evidência a partir do período babilônico antigo (século XVII a. C.) de que o palácio concedia empréstimos de consumo. Não está claro, contudo, se os beneficiários desses empréstimos permaneciam em relação direta com o palácio, por exemplo, como empregados ou membros da household palacial, e assim naturalmente recebiam tais empréstimos do palácio, ou se esses empréstimos eram dados a estrangeiros. ${ }^{43}$ É o ambiente social que determina, a um grau maior, as condições de acordo com as quais os empréstimos são concedidos ou outras obrigações contratuais aceitas. É obvio que o crédito representava um papel importante na economia da antiga Mesopotâmia.

\footnotetext{
${ }^{42}$ RENGER, Johannes. On economic structures in ancient Mesopotamia. Orientalia, n. 63, 1994, p. 157-208, especialmente p. 195.

${ }^{43}$ Idem, p. 197.
} 
Está plenamente claro, contudo, que as diferentes formas de crédito têm de ser meticulosamente distinguidas e toda atenção tem de ser prestada para as diferenças em época, ambiente social e esferas econômicas. Empréstimos de consumo são amplamente atestados; adiantamentos, crédito e contratos de empréstimos fictícios eram usados para promover operações econômicas dentro de households institucionais e, ao tratar de terceiros, fora da household. Empréstimos comerciais eram restritos a empreendimentos comerciais. Isso é bem documentado para o começo do segundo milênio tanto na Assíria como na Babilônia, bem como para o período neobabilônico (séculos VI-V a. C.). Mas nada prova a existência de empréstimos dados para propósitos lucrativos, isto é, produção manufatureira ou agrícola, que induza crescimento econômico. Muito pelo contrário! Possuir superávit adquirido, tal como, em um empreendimento comercial, a partir de reinvestimento, e convertê-lo, por exemplo, em bens de raiz, serve para aumentar o status social de alguém. Finalmente, não possuímos qualquer prova para um mercado de empréstimo onde oferta e demanda tenham influenciado as condições para empréstimos (por exemplo, taxas de juros etc.). Também a escravidão ou servidão contratual, isto é, o direito de um indivíduo livre para afiançar-se ou a um membro familiar como garantia para um empréstimo, não requer a existência de um mercado de crédito. A taxa invariável de juro durante os séculos constitui um forte argumento contra a existência de um mercado de crédito. Se tivesse havido um mercado de crédito, no verdadeiro sentido da palavra, esperar-se-iam taxas variáveis de acordo com a oferta e a demanda.

\section{Os novos modelos: a perspectiva de Liverani}

Para compreender a coexistência de modelos de interpretação diferentes e que conduzem a conclusões históricas tão contraditórias, é preciso considerar que os textos econômicos mesopotâmios são difíceis de ler e interpretar. Seu formato, seu léxico, as práticas de verificação e legalização, embora repetidos por vezes sobre milhares de documentos, não nos são muito claros. De mais, somente as relações econômicas associadas à acumulação e à redistribuição de bens no quadro de instituições urbanas foram sistematicamente registradas pela escrita cuneiforme e conservadas nos arquivos: não se deve inferir que elas representaram todas as trocas no mundo antigo. Embora sendo proporcionalmente bem inferior em quantidade, uma documentação relativa a outros tipos de relações e de estratégias econômicas existe também, e continua muito significativa: para além do corpus das cartas dos comerciantes assírios na Capadócia, já citados, podem ser mencionados, por exemplo, os 
contratos de venda que refletem a propriedade privada da terra e bens imobiliários. Pela própria natureza privada, entre os indivíduos, esses textos econômicos têm uma estrutura mais complexa, articulada e variável. Eles foram conservados por razões diferentes daquelas dos textos institucionais, e eles têm sobrevivido mais aleatoriamente. Esta realidade convida a ter cautela na interpretação e na explicação dos fatos e das estruturas econômicas, e explica também como os mesmos dados textuais podem oferecer possibilidades de leitura diferentes e mesmo contraditórias. Desde a década de 1970, vários assiriólogos e historiadores do antigo Oriente Próximo, como Mário Liverani, Carlo Zaccagnini, M. T. Larsen, K. Veenhof, N. Yoffe, N. J. Postgate, M. van de Mieroop, G. Van Driel, têm começado a reconstituir o desenvolvimento econômico do mundo mesopotâmio no seu quadro histórico. Usando todas as fontes documentais arqueológicas e textuais, em diferentes níveis, eles procuraram destacar as fases da evolução da economia e do mercado. Enfatizando diferentes aspectos da mudança do sistema econômico antigo - mas, basicamente, sem renunciar completamente a todos os pressupostos polanyianos - esses historiadores estão tentando restaurar uma imagem da economia mesopotâmia como aquela de economia de mercado, mas sem as propriedades e características do mercado moderno e contemporâneo. ${ }^{44}$

Estas reconstruções, apesar das diferenças significativas, apresentam pontos em comum. Todos parecem concordar que o Estado, por meio de sua política e suas instituições, ainda pesa sobre o funcionamento do mercado, que não pode ter o aspecto mecânico e independente em relação às estruturas sociais que lhe são atribuídas pela teoria econômica moderna. Eles também levam em conta a falta, na Mesopotâmia antiga, de uma medida comum, de uma moeda para quantificar o valor das matérias primas, dos produtos e, sobretudo, do trabalho humano, e para expressá-lo por preços determinados pelo equilíbrio entre a oferta e a demanda. Em segundo lugar, todos já admitem a existência e a relevância de um mercado comercial, autônomo das redes de intercâmbio "recíprocas" entre estados e instituições. Este mercado se estabelece no seio de uma categoria de especialistas, os mercadores, que têm códigos de comportamento com procedimentos profissionais determinados. ${ }^{45}$

A historiografia marxista acerca da economia do antigo Oriente Próximo encontra em Carlo Zaccagnini e Mario Liverani uma formulação mais sofisticada do modo de produção asiático, caracterizado pela propriedade

\footnotetext{
${ }^{44}$ MASETI-ROUAULT, Maria Grazia, op. cit., p. 58-59.

${ }^{45}$ MASETI-ROUAULT, Maria Grazia, op. cit., p. 59.
} 
comunal, sendo a aldeia um produtor econômico autônomo; pelo déspota como o proprietário final da terra e angariando tributo por meio do trabalho forçado; e a não diferenciação do trabalho e do campo. Liverani afirmou que o modo de produção asiático articulava dois modos de produção, o palacial e o aldeão, sendo o segundo dominado pelo primeiro. Para além da distinção das atividades aldeãs das atividades das grandes organizações do Estado, o modelo mostrava-se problemático em relação às explicações das mudanças econômicas, apesar de observáveis.

Para além do instrumental marxista, Liverani tem avançado muito na análise da economia e da sociedade do antigo Oriente Próximo em uma perspectiva histórica. Ele escreveu um capítulo na coletânea organizada por Ian Morris e J. Manning intitulada The ancient economy: Evidence and models, em 2005, no qual procura apresentar uma visão geral da economia do antigo Oriente Próximo do terceiro ao primeiro milênio, mesmo considerando a enorme série de dados e as diferenças das unidades culturais - de estepe e verdadeiro deserto até montanhas arborizadas, de clima mediterrâneo até árido, de agricultura sustentada por chuva até redes de irrigação, de centros urbanos até acampamentos pastorais, de estados burocráticos até tribos esparsas. O modelo de Liverani complementa e aprofunda o de Ranger investigado anteriormente e parece-nos o mais sofisticado, pois articula as estruturas econômicas da Mesopotâmia com as transformações históricas relacionadas com a política e o comércio.

Segundo Liverani, as estruturas básicas das economias do antigo Oriente Próximo foram estabelecidas desde a revolução urbana, no final do IV milênio a. C., e ficaram estáveis até a grande crise do final do II milênio a. C. A Idade do Bronze, criada como um recurso classificatório para ferramentas e armas, pode ainda ser usada como um rótulo histórico, abrangendo similarmente sistemas socioeconômicos estruturados e opostos aos períodos precedentes e subsequentes. ${ }^{46}$

A denominação "cidade-templo" significa um modelo de economia em que um setor específico relevante modela a economia inteira da cidade ou do Estado. Um dado setor é o mais importante em comparação aos outros, influenciando de vários modos e graus os outros setores também. Em termos gerais: se queremos avaliar um modelo de uma economia, nós temos de avaliar os estudos quantitativos de suas partes componentes e compreender

\footnotetext{
${ }^{46}$ LIVERANI, Mario. The near East: The Bronze Age. In: MANNING. Joseph Gilbert \& MORRIS, Ian. The ancient economy. Evidence and models. Stanford, California: Stanford University Press, 2005, p. 48.
} 
o funcionamento interno da cidade como uma "cidade-templo", não porque o templo era a única representação econômica, mas porque era de longe o maior agente, capaz de influenciar os outros, menores. ${ }^{47}$

Parece haver consenso entre assiriólogos com a ideia de que as propostas de Polanyi sobre comércio estavam erradas - embora outra proposição principal de Polanyi, sobre a natureza redistributiva da economia do antigo Oriente Próximo, tenha sido mais bem recebida. Para Liverani, a afirmação de comércio administrado versus privado é uma questão de quantidade e qualidade. Tal avaliação deveria também ser diferenciada de acordo com o período. O papel do templo foi especialmente relevante durante o início da Idade do Bronze e o comércio administrado culminou sob a terceira dinastia de Ur (2112-2004 a. C.). O papel da empresa privada foi relevante durante a Idade do Bronze intermediária, século XXI a. C., com a atividade dos mercadores dos antigos períodos assírio e babilônico. Finalmente, o comércio administrado pelo palácio experimentou um aumento renovado durante a Idade do Bronze tardia (séculos XVI- XII a. C.), especialmente na forma de troca cerimonial entre a corte real.

Um segundo ponto, e mais importante, é que o comércio pode ser subdividido em dois segmentos básicos. O primeiro concerne à relação entre o templo ou palácio e seus agentes de comércio; o segundo segmento está relacionado com as atividades dos mercadores, uma vez que eles deixavam seu país natal e se aventuravam em terras estrangeiras; o segmento final está relacionado aos ajustes de contas entre mercadores e representações centrais no final do processo. A relação administrativa, usando valores fixos e buscando materiais indisponíveis na pátria, se modificava no final do processo: agentes do comércio obtinham prata e/ou materiais processados (principalmente metais e têxteis) vindos da representação central e tinham de trazer de volta depois de seis meses ou um ano o equivalente em produtos exóticos ou matérias primas. A balança econômica entre a representação central e os agentes do comércio não podia, contudo, ser regulada por valores de troca fixos. Mas a atividade dos mercadores, logo que eles deixavam o palácio, era completamente diferente: eles podiam livremente comercializar, tirando proveito dos diferentes preços dos vários itens em vários países, mesmo usando sua moeda em atividades financeiras (tais como empréstimos) nesse tempo à sua disposição, e procurando lucro pessoal máximo possível. Do-

${ }^{47}$ Idem, p. 50. 
cumentos pertinentes à relação entre o templo ou palácio e seus agentes de comércio, no início e no final do processo, certamente nos darão a impressão de um comércio administrado, enquanto que os documentos pertinentes aos segmentos intermediários, isto é, aqueles relacionados com as atividades dos mercadores no exterior, nos darão a impressão do comércio livre. As duas impressões estão ambas corretas e não se contradizem.

A relação entre ofícios e representações centrais é também o assunto de um debate similar (embora menos intenso), que pode ser resolvido junto com as mesmas linhas. No antigo modelo da cidade-templo, os artífices eram arrolados dentro de grupos da representação central, processando matérias primas dadas pela própria instituição, que sucessivamente apoiava os artífices por meio do sistema de ração (nos primeiros estágios) ou por meio de loteamentos de terra (nos últimos estágios). Em sua última formulação, esse modelo representa a instituição central como o único "cliente" dos artífices e representa todos os artífices como dependentes íntimos (tempo integral) da agência central, deixando para a população "livre" somente a tarefa de produzir alimento. Porém, marcas de ofícios especializados (metal, escórias, objetos de cerâmica, lascamentos líticos e assim por diante) estão, de fato, presentes em sítios menores, e elementos dos centros administrativos, como cones de argila em Uruk tardia, são encontrados em pequenos assentamentos. A objeção da visão de concentração urbana é a referência a ofícios nas vilas e em ambientes familiares, com uma pluralidade de compradores, visto que seus produtos não eram somente destinados a atividades de luxo (ou a evidente consumo) pela elite, ou para armazenamento em palácios ou templos, mas também para as necessidades normais e frequentes da população toda.

Essa análise deturpa o modelo de concentração urbana de ofícios especializados? Certamente que não. A avaliação final deve levar em conta tanto a quantidade como a qualidade. Enquanto alguns ofícios eram comuns em aldeias e conduzidos por famílias individualmente, os mais importantes e mais complexos estão localizados dentro, em torno ou ligados à representação central - por si mesmo, o maior consumidor de produtos finais, a maior concentração de trabalhadores e, de longe, a reunião mais eficaz de matérias primas (locais e exóticas igualmente).

A perspectiva de Liverani complementa a análise de Renger ao incluir setores não palaciais/templários na estrutura econômica. Renger focou as estruturas centrais, autárquicas, mas não aprofundou para este período o papel de outros setores. A inclusão do setor comunal, inicialmente desenvolvido por Diaknoff, trouxe ao debate um novo ator econômico e político. Mesmo com todas as dificuldades que as fontes apresentam, essa perspec- 
tiva relativizou o papel do setor "privado" e esclareceu melhor o papel das instituições centrais.

Em outro artigo, intitulado "The influence of political institutions on trade in the ancient near East (late Bronze to early Iron Age)", no livro organizado por Carlo Zaccagnini, Mercanti e politica nel mondo antico, Liverani contextualiza historicamente a influência das instituições políticas no comércio no final da Idade do Bronze e início da Idade do Ferro, com uma abordagem estrutural focada nos impactos das políticas nos modelos de comércio. Liverani explora a transição do período do Bronze para o Ferro para contrapor dois cenários particularmente diferentes tanto na tipologia política como nos modelos comerciais. O primeiro cenário, cobrindo os séculos XIV ao XIII a. C., é bem documentado, enquanto o segundo cenário se torna totalmente documentado somente no decurso do tempo. As diferenças são marcantes, e é uma suposição razoável que a transição tenha sido particularmente rápida e levou não mais do que alguns séculos para se materializar totalmente. ${ }^{48}$

Durante a Idade tardia do Bronze, o controle exercido pelo palácio na economia inteira e especialmente em habilidades especializadas e no comércio foi durante esse período um dos pontos culminantes na história toda do antigo Oriente Próximo. Tanto os reis "pequenos" quanto os "grandes" tinham seus próprios mercadores (tamkāru), que costumavam deixar o palácio com um dote real (mandattu) e tinham de trazer de volta matérias primas e mercadorias indisponíveis em sua pátria. No caso mais específico de itens preciosos de comércio, o palácio e os membros da elite do palácio parecem ter sido mais ativos em requerer e usar produtos de luxo de artífices locais ou estrangeiros, e em procurar por metais preciosos (especialmente o ouro egípcio) a fim de financiar os programas de construção públicos. Os reis pessoalmente negociavam o estabelecimento de relações comerciais, pediam isenções fiscais para seus próprios mercadores, e oficialmente protestavam contra roubos e assassinatos que aconteciam no território de seus parceiros. Mercadores estrangeiros eram regularmente hospedados nos palácios reais, recebendo comida e bebida durante o estágio deles. Em alguns casos, os mercadores realmente estavam atuando como agentes para o palácio real (financiado pelo rei, comercializando em seu nome), mas em outros casos, o rei simplesmente cuidava dos mercadores privados que eram seus súditos, membros do regime regido por ele. A mistura de negócios públicos e

\footnotetext{
${ }^{48}$ LIVERANI, Mario (ed.). The influence of political institutions on trade in the ancient near East. In: ZACCAGNINI, Carlo. Mercanti e politica nel mondo antico. Roma: L'Erma di Bretschneider, 2003, p. 120.
} 
privados pelos mercadores reais é particularmente óbvia, mas compõe um cenário mais complexo e menos distinto.

Esta realidade começa a mudar com a crise do século XII a. C., que finalizou na Idade do Bronze e foi, pelo menos em parte, causada por aqueles grupos que, no período anterior, estavam a agir fora ou contra o sistema comercial: piratas no Mediterrâneo oriental, pastores na estepe síria. Indubitavelmente, a atividade deles paralisou o comércio durante o período mais forte da crise. Em todo o caso, a crise começou no final do século XIII a. C. com a fome alastrada, especialmente na Anatólia, e com as primeiras levas dos povos marítimos. A crise alcançou seu ápice na segunda década do século XII a. C. com maciças destruições de cidades centradas no palácio, especialmente as costeiras, devido à principal leva dos povos marítimos. A crise continuou durante um par de séculos, especialmente no interior da Síria e Palestina, e na alta Mesopotâmia, por meio da infiltração das tribos arameias (ou próximas) as quais com o passar dos anos encontraram seu caminho até a fronteira elamita. Um fenômeno paralelo é a infiltração de tribos líbias no Egito, especialmente a oeste do delta e do fayum.

Na Idade do Ferro, a partir do século XI a. C., o comércio era realizado por grupos especializados: oligarquias de mercadores na costa mediterrânea, tribos de criadores de camelo na zona árida. As estratégias comerciais, uma vez subordinadas às decisões políticas, agora estão em condição de influenciá-las. A existência de cidades inteiras ou comunidades especializadas e devotadas ao comércio é algo novo na Idade do Ferro: completamente novo comparado com a Idade tardia do Bronze, e novo em valor ou grau comparado com as condições iniciais dos períodos antigos da Assíria e da Babilônia. Contudo, as principais rotas comerciais na Idade do Ferro aparentemente evitavam passar através dos principais mercados e das principais concentrações de pessoas nos antigos estados regionais do Egito e da Babilônia. As principais rotas passavam entre elas, ligando os portos e as cidades de caravana com as remotas fontes de metais e mercadorias exóticas. As mercadorias comercializadas chegavam aos principais mercados somente de forma secundária, mas a primazia das empresas comerciais definitivamente deixou os antigos estados regionais e focou nas novas e muito menores comunidades comerciais. Tal completa reestruturação da organização comercial é um dos traços mais importantes em época de crise no final da Idade do Bronze, em todo o Oriente Próximo e nas áreas adjacentes.

A análise de Liverani demonstra que um tipo de comércio, diferente do período do Bronze, predominantemente voltado para o lucro e autonomia dos comerciantes, não estava centrado na região mesopotâmia, mas fora dela. 
A Mesopotâmia pode ter sofrido influência, daí a liberdade dos comerciantes para comercializar, inclusive com lucros, quando saíam dos palácios. Mas as novas rotas do comércio amparado no ganho se encontravam em outra região. Este é um elemento importante para se acreditar que os "formalistas" procuram na Mesopotâmia um tipo de comércio e, consequentemente, de mercado que, na verdade, não tinha seu centro lá, pois as mutações ocorridas no final da Idade do Bronze não atingem estruturalmente o comércio na Mesopotâmia.

\section{Conclusão}

Polanyi cai na armadilha de demarcar uma linha divisória entre o "antigo" e o "moderno" por meio do mercado. Mais especificamente pelo mercado criador de preços, recente e artificial, produto de transformações históricas e sociais. O "antigo" é contraposto ao "moderno" pela ausência do intercâmbio regido pelo regateio, efetuado em uma instituição específica, o mercado.

Para Yves Roman, os historiadores devem romper com os discursos de exclusão que, por um lado, conforme os seguidores da teoria smithiana, atrelam a economia de mercado ao aparecimento do capitalismo, assimilando-o a uma lei natural que garante a realização do equilíbrio global, capaz de proporcionar o bom funcionamento da economia; ou, por outro, se alinham com os trabalhos dos antropólogos Malinowsky e Mauss, no qual a economia antiga se encontra em um mundo primitivo dominado pelo dom e contradom, sem troca, moeda e capital. Tanto uma perspectiva quanto a outra apresentam uma clivagem entre o presente e o passado. Cabe ao historiador realizar um inventário paciente, preciso e metódico, questionando as categorias estabelecidas por economistas e antropólogos econômicos sem, necessariamente, excluir modelos utilizados para entender a economia do mundo contemporâneo em sociedades antigas, pois o mercado deve ser visto em uma perspectiva de longuíssima duração. ${ }^{49}$

Ao se reportar ao mundo antigo como diferente e distinto em relação ao papel do mercado, Polanyi incorre em um equívoco grave, advindo da antropologia funcionalista, preocupada com os aspectos integrativos da sociedade: acredita que o homem é "naturalmente" propenso às relações de

\footnotetext{
${ }^{49}$ ROMAN, Yves. Introduction. Une question difficile pour les héritiers d'Hérodote et "les enfants d'Adam Smith": l'economie antique, une economie de marché? In: ROMAN, Yves E DALAISON, Julie. L'économie antique, une économie de marché? Actes des deux tables rondes tênues à Lyon les 4 février et 30 novembre 2004. Paris: Soc. des Amis de J. Spon, De Boccard, 2008, p. 7-13.
} 
reciprocidade e redistribuição. Se não estamos no mundo moderno, então as relações de reciprocidade e redistribuição são predominantes, porque tais sociedades não se encontram dominadas pela ficção e artificialidade da sociedade regida pelo ganho e lucro. É certo que a sociedade moderna cria uma série de ficções em torno da troca e do mercado. Mas é certo, também, que muitas características do mercado moderno se encontram em sociedades "primitivas", muito distintas entre si. É um erro colocar todas estas sociedades primitivas no mesmo cadinho. As relações de reciprocidade e redistribuição podem conviver "lado a lado" com as relações de mercado sem necessariamente serem subordinadas ou dominantes. Portanto, é possível encontrar elementos não mercantis desempenhando um papel relevante no interior da economia capitalista, imersas nas relações sociais.

Além disso, entre o "antigo" e o "moderno", as diferenças são qualitativas e não quantitativas. Encontrar elementos do mercado autorregulável nos mercados antigos - impessoalidade, flutuação de preços - não significa classificar tais sociedades como mercantis no sentido moderno do termo, porque o "grau" de integração de tais mercados na sociedade é diferente. Na Mesopotâmia, as formas de integração redistributivas tendo as instituições centrais templo/palácio - como atores políticos fundamentais não eliminaram a possibilidade de ganhos privados e mesmo do mercado em algumas ocasiões.

Contudo, tais mercados se encontram em uma realidade muito diversa dos mercados das sociedades modernas, mesmo se lá encontramos algumas características do mercado autorregulável, estabelecidas por Polanyi para o mundo moderno. Mas tais diferenças e descontinuidades não se explicam pela propensão natural à reciprocidade e à redistribuição em oposição ao intercâmbio realizado no mercado, mas sim pelo caráter cultural específico que cada sociedade atribui às suas atividades de intercâmbio, articuladas com o papel desempenhado pelas permutas nos diferentes modos de produção.

Por fim, vale ressaltar que após o início do debate da economia antiga, que se iniciou no século XIX, na Alemanha, entre "primitivistas" e "modernistas", muito se avançou na pesquisa assiriológica em relação aos primeiros modelos interpretativos da economia mesopotâmia. Não só em relação à documentação cuneiforme, mas também em relação aos trabalhos empíricos. Nesse sentido, se não há hoje uma teoria aceita por todos em relação à economia antiga, a pergunta de como essas economias mudam continua sendo pertinente. A existência e os tipos de mercado, tal como colocado por Polanyi, se encontram superados, mas o lugar das trocas no sistema social não. A relação entre as households e o mercado, pensada em sua diversidade espacial e temporal é muito pertinente na atualização do debate, conforme 
questionou David Snell. Afinal de contas, de acordo com Marcelo Rede, ${ }^{50}$ não se devem preencher as lacunas da documentação fragmentada com a teoria, porém, não se pode abrir mão da teoria para orientar a interpretação dos eventos, para não se correr o risco destes eventos permanecerem enclausurados em sua singularidade e impotentes do ponto de vista do conhecimento.

\section{Referências bibliográficas}

CARVALHO, Alexandre Galvão. Historiografia e paradigmas: a tradição primitivista-substantivista e a Grécia antiga. Tese de doutorado, Universidade Federal Fluminense, Niterói, 2007.

CLANCIER, Philippe et al. (ed.). Autour de Polanyi. Voccabulaires, théories et modalités des échanges. Paris: De Boccard, 2005.

DEIMEL, Anton. Sumerische Tempelwirtschaft zur Urukaginas und seinerVorgänger. Roma, 1931.

FALKENSTEIN, Adam. La cité-temple sumérienne. In: Cahiers d'histoire mondiale, v. 1, 1954, p. 784-814.

GELB, Ignace Jay. On the alleged temple and state economies in ancient Mesopotamia. Studi in Onore di Edoardo Volterra, v. 6, Milão, 1969, p. 137-154.

GLEDHILL, John $\&$ LARSEN, Mogens. The Polanyi paradigm and a dynamic analysis of archaic states. In: RENFREW, Colin; ROWLANDS, Michael; SEGRAVES, Barbara Abbott (ed.). Theory and explanation in archaeology. Nova York: Academic Press, 1982.

LEVITT-POLANYI, Kari. The life and work of Karl Polanyi. Montreal: Black Rose Books, 1990.

LIVERANI, Mario. Il modo di produzioni. In: MOSCATI, Sabatino (org.). L'Alba dela civiltà, vol II: L'economia, Turim, 1976, p. 1-126.

(ed.) The influence of political institutions on trade in the ancient near East. In: ZACCAGNINI, Carlo. Mercanti e politica nel mondo antico. Roma: L'Erma di Bretschneider, 2003.

The near East: The Bronze Age. In: MANNING, Joseph Gilbert $\mathcal{E}$ MORRIS, Ian. The ancient economy. Evidence and models. Stanford, California: Stanford University Press, 2005, p. 47-57.

MANNING, Joseph Gilbert $\mathcal{E}$ MORRIS, Ian. The ancient economy. Evidence and models. Stanford, California: Stanford University Press, 2005.

MASETI-ROUAULT, Maria Grazia. Économie de redistribution et économie de marché au proche-Orient ancien. In: ROMAN, Yves E DALAISON, Julie. L'économie antique, une économie de marché? Actes des deux tables rondes tênues à Lyon les 4 février et 30 novembre 2004. Paris: Soc. des Amis de J. Spon, De Boccard, 2008.

MAUCOURANT, Jérôme. Le marché, une institution entre économie et histoire. Cahiers lillois d'économie et de sociologie, n. HS-2006, 2007, p. 87-108. Disponível em: http://halshs.archives-ouvertes.fr/halshs-00190874/fr/. Acesso em: 11/06/2013.

${ }^{50}$ REDE, Marcelo. Família e patrimônio na Mesopotâmia. Rio de Janeiro: Mauad X, 2007, p. 194. 
Avez vous lu Polanyi? Paris: Flamarion, 2011.

NAFISSI, Mohammad. Ancient Athens \& modern ideology. Value, theory E evidence in historical sciences. Max Weber, Karl Polanyi \& Moses Finley. Londres: Institute of Classical Studies, 2005.

POLANYI, Karl. A grande transformação: as origens da nossa época. Tradução de Fanny Wrobel. $8^{\mathrm{a}}$ edição. Rio de Janeiro: Campus, 2000.

POLANYI, Karl; ARENSBERG, Conrad; PEARSON, Harry. Comercio y mercado en los imperios antiguos. Tradução de Alberto Nicolás. Barcelona: Labor Universitaria, 1976.

POLANYI, Karl. The livelihood of man. Nova York; São Francisco; Londres: Academic press, 1977.

On the comparative treatment of economic institutions in Antiquity with illustrations from Athens, Mycenae, and Alalakh. In: DALTON, George. Primitive, archaic and modern economies. Essays of Karl Polanyi. Boston: Beacon Press, 1968, p. 306-334.

REDE, Marcelo. Família e patrimônio na Mesopotâmia. Rio de Janeiro: Mauad X, 2007.

Da sociedade-templo à cidade-reino na antiga Mesopotâmia: Aspectos da transição. In: ALDROVANDI, Cibeli; KORMIKIARI, Maria Cristina; HIRATA, Elaine Farias (org.). Estudos sobre o espaço na Antiguidade. São Paulo: Fapesp, 2011.

RENGER, Johannes. On economic structures in ancient Mesopotamia. Orientalia, n. 63,1994 , p. 157-208.

Trade and market in the ancient near East. Theoretical and factual implications. In: ZACCAGNINI, Carlo (ed.). Mercanti e politica nel mondo antico. Roma: L'Erma di Bretschneider, 2003, p. 15-39.

ROMAN, Yves \& DALAISON, Julie. L'économie antique, une économie de marché? Actes des deux tables rondes tênues à Lyon les 4 février et 30 novembre 2004. Paris: Soc. des Amis de J. Spon, De Boccard, 2008.

SÁRKANY, Mihály. Karl Polanyi's contribution to economic anthropology. In: LEVITT-POLANYI, Kari. The life and work of Karl Polanyi. Montreal: Black Rose Books, 1990, p. 183-187.

SERVET, Jean-Michel; MAUCOURANT, Jérôme; TIRAN, André. La modernité de Karl Polanyi. Paris: éd. L'Harmattan, 1998.

SILVER, Morris. Karl Polanyi and markets in the ancient near East: The challenge of the evidence. The Journal of Economic History, v. 43, n. 4, 1983, p. 795-829. Disponível em: http://dx.doi.org/10.1017/S002205070003076X.

SNELL, David. Life in the ancient near East. New Haven; Londres: Yale University Press, 1997.

TANDY, David $\mathcal{E}$ NEALE, Walter. Karl Polanyi's distinctive approach to social analysis and the case of ancient Greece: ideas, criticism, consequences. In: DUNCAN, Colin \& TANDY, David. From political economy to anthropology. Situating economic life in past societies. Montreal: Black Rose Books, 1994.

ZACCAGNINI, Carlo (ed.). Mercanti e politica nel mondo antico. Roma: L'“Erma”. 2003.

Recebido: 21/10/2014 - Aprovado: 10/06/2015 
